\title{
Entomopathogenic nematodes for the control of Gryllus sp. (Orthoptera: Gryllidae) under laboratory and field conditions
}

\author{
Nematoides entomopatogênicos no controle de Gryllus sp. \\ (Orthoptera: Gryllidae) em condições de laboratório e campo
}

\author{
Vanessa Andaló1* (iD, Kellin Patrícia Rossati ${ }^{1}$, Fábio Janoni Carvalho' ${ }^{(1)}$, Jéssica Mieko', \\ Lucas Silva de Faria' ${ }^{(\mathbb{D})}$, Gleice Aparecida de Assis ${ }^{1}$ (D), Leonardo Rodrigues Barbosa²
}

\begin{abstract}
Entomopathogenic nematodes are effective in controlling soil insects and they are used in agricultural systems. The virulence of entomopathogenic nematodes on crickets (Gryllus L.) (Orthoptera: Gryllidae) was evaluated under different conditions in order to select populations for application in the field. Virulence tests with Heterorhabditis amazonensis RSC05, $H$. amazonensis MC01, Steinernema carpocapsae All (Weiser) and $H$. amazonensis GL were performed. Evaluations were then made of the concentrations of infective juveniles (100, 200, 400 and 600 infective juveniles per insect); feeding preference with or without choice; and field tests using traps to evaluate insect sampling. All isolates were found to cause mortality in Gryllus sp., and H. amazonensis MC01 and S. carpocapsae All were selected; an increase in concentration resulted in increased insect mortality. Regarding the feeding preference tests, after $16 \mathrm{~h}$ there was no feeding in any of the treatments. In treatments with a chance of choice, it was verified that the crickets fed, independently of the presence of the nematodes. In the field tests, 19 live crickets were found in the traps, and, after application of entomopathogenic nematodes in aqueous suspension, 2 live crickets were found. Results suggested that $H$. amazonensis $\mathrm{MC01}$ was promising in the control of Gryllus sp. under the tested conditions.
\end{abstract}

KEYWORDS: biological control; cricket; Heterorhabditis; horticulture; Steinernema.
RESUMO: Os nematoides entomopatogênicos (NEPs) são eficazes contra insetos de solo e têm sido usados em sistemas agrícolas. A ação de NEPs sobre grilos (Gryllus L.) (Orthoptera: Gryllidae) foi avaliada em condiçóes de laboratório e campo, a fim de selecionar populaçóes para aplicaçáo em área de cultivo. Foram realizados testes de virulência com Heterorhabditis amazonensis RSC05, H. amazonensis MC01, Steinernema carpocapsae All (Weiser) e H. amazonensis GL, assim como verificadas a adequação da concentração de juvenis infectantes (100, 200, 400 e 600 juvenis infectantes por inseto) e a preferência alimentar sem chance de escolha e com chance de escolha, além do teste de campo utilizando armadilhas para amostragem dos insetos. Verificou-se que todos os isolados causaram mortalidade em Gryllus sp. selecionando-se H. amazonensis MC01 e S. carpocapsae All e que o aumento na concentração de juvenis infectantes resultou em mortalidade crescente dos insetos. Com relaçáo aos testes de preferência alimentar, observou-se que, após 16 horas, não houve alimentação em nenhum dos tratamentos. Nos tratamentos com chance de escolha, constatou-se que houve alimentação dos grilos, independentemente da presença ou não de nematoides. Nos testes de campo, antes da aplicação de juvenis infectantes, foram encontrados 19 grilos vivos nas armadilhas, e após a aplicaçáo dos NEPs em suspensão aquosa foram encontrados 2 grilos vivos. Dessa forma, concluiu-se que $H$. amazonensis MC01 foi promissor no controle de Gryllus sp. nas condiçōes testadas.

PALAVRAS-CHAVE: controle biológico; grilo; Heterorhabditis; horticultura; Steinernema. 


\section{INTRODUCTION}

Crickets are polyphagous insect pests that cause economic damage in agricultural areas. Gryllus assimilis (Fabricius) (Orthoptera: Gryllidae) and Anurogryllus muticus (De Geer) (Orthoptera: Gryllidae) are among the leading species causing damage to crops in Brazil. These insects feed on the surface or cut and carry parts of plants into the soil, especially after the emergence of plants (SALVADORI, 1999). They are responsible for attacking vegetables in nurseries and in the field, but also occur sporadically in crops such as cotton, rice, soybean, maize, sunflower, and pasture (MOREIRA; ARAGĀO, 2009).

These insects feed on seedlings, leaves, branches and plant roots. They are nocturnal and live in environments with low vegetation or crops with scarce vegetation cover. During the day, they remain hidden under debris and in underground galleries, in damp and dark environments. Even low densities such as 1 insect $/ \mathrm{m}^{2}$ can cause considerable damage in maize and soybeans at the germination stage (GASSEN, 1996; SANTOS et al., 2008).

The subterranean habits of this insect make its control in the field difficult and costly, and in some cases standard control techniques are not suitable. In lettuce crops, for example, there are no registered chemical insecticides for cricket control (BRASIL, 2017). Therefore, the use of biological control with entomopathogenic organisms can become a viable alternative for pest control.

Entomopathogenic nematodes of the families Steinernematidae and Heterorhabditidae (Nematoda: Rhabditida) are insect parasites that pass part of their life cycle in the soil and kill the host $24-48 \mathrm{~h}$ after gaining entry. In addition, they have potential for long-term establishment in the soil through their reproduction in infected hosts, producing infective juveniles that will leave the cadaver and search for new hosts (GRIFFIN et al., 2005). These nematodes carry symbiotic bacteria of the genera Photorhabdus (Boemare) and Xenorhabdus (Thomas \& Poinar), which, when released in the host, cause their death (DOLINSKI; MOINO JÚNIOR, 2006).

Entomopathogenic nematodes vary in their host range (KAYA; GAUGLER, 1993; ANDALÓ et al., 2010). Thus, the selection of the most appropriate species and strain is important in maximize the control of Gryllus sp. In this way, our objective was to evaluate the virulence of several isolates of entomopathogenic nematodes on Gryllus sp. under laboratory and field conditions, in order to select species for application in the field in control programs.

\section{MATERIALS AND METHODS}

\section{Rearing Gryllus sp. in the laboratory}

Adults of Gryllus sp. were collected from rural properties in the region of Monte Carmelo, Minas Gerais, Brazil. Rearing of the insects was conducted in a climate-controlled chamber at
$25 \pm 2^{\circ} \mathrm{C}, 70 \pm 10 \%$ relative humidity $(\mathrm{RH})$ and photoperiod of 12:12 h L:D, as described by BARBOSA et al. (2009).

After collection, the insects were kept in plastic boxes $(56 \times 38 \times 37 \mathrm{~cm})$, with the top opening closed with galvanized screen for aeration, and containing three or four cardboard trays $(29 \times 10.5 \times 7 \mathrm{~cm})$, to increase the inner surface area and to decrease cannibalism.

The insects were fed with Magnus ${ }^{\circledR}$ dog-food and supplied with water in Petri dishes (11 cm of diameter), with moistened cotton. For egg production, Petri dishes (11 cm of diameter) containing moistened cotton as an oviposition substrate were kept in the plastic boxes for 3-4 days. The eggs were collected and stored in Petri dishes (11 cm of diameter) containing filter paper, at $100 \%$ RH, and sealed with Parafilm ${ }^{\circledR}$.

After 15 days under the aforementioned rearing conditions, newly hatched nymphs were transferred to plastic boxes $(26 \times$ $17 \times 14 \mathrm{~cm}$ ), using the same methodology adopted for adults.

\section{Multiplication of entomopathogenic nematodes}

Infective juveniles were cultured in Tenebrio molitor $\mathrm{L}$. (Coleoptera: Tenebrionidae) larvae reared according to the methodology of POTRICH et al. (2007). The killed larvae with symptoms of infection were washed with Ringer's solution and placed in a dry chamber $(9 \mathrm{~cm}$-diameter Petri dish with filter paper) for 5 days, and then were placed in WHITE (1927) traps to collect the infective juveniles (MOLINA; LÓPEZ, 2001). Infective juveniles collected from 3-5 days after emergence were used for the experiments.

\section{Virulence of entomopathogenic nematodes on Gryllus sp.}

The virulence of Heterorhabditis amazonensis RSC05 (ANDALÓ et al., 2010), $H$. amazonensis MC01, $H$. amazonensis GL, and Steinernema carpocapsae All (Weiser) was tested in Gryllus sp. under laboratory conditions. Ten nymphs of 2 nd and 3rd instar Gryllus sp. were placed in Petri dishes (15 cm of diameter) containing filter paper moistened with $1 \mathrm{~mL}$ of sterile distilled water, and then $1.5 \mathrm{~mL}$ of suspension with 2,000 infective juveniles of each species of entomopathogenic nematodes was applied. Three replicate dishes with nymphs were used for each nematode isolate and for the untreated control. The dishes were closed with Parafilm and stored at $24 \pm 2^{\circ} \mathrm{C}$ with a photoperiod of 0:24 h L:D. After 10 days, the numbers of dead individuals were recorded, and the percentage of confirmed mortality for each isolate was evaluated.

Mortality caused by nematodes was confirmed by dissecting the cricket cadavers. For data analysis, a variance analysis (ANOVA) was performed, and later the normality and homogeneity assumptions were met. The means obtained for each nematode were analyzed using the Tukey test $(\mathrm{p}<0.05)$. 


\section{Concentration of infective juveniles on Gryllus sp.}

The infective juveniles of $H$. amazonensis MC01 and $S$. carpocapsae All were selected for further study, because they caused high mortality in the previous test, and were applied to 3rd and 4th instar nymphs of Gryllus sp. at concentrations of 100, 200, 400 and 600 infective juveniles per dish using the same methodology described previously. Three replicates were conducted with 10 nymphs for each nematode at each concentration and control (water). Data obtained from confirmed mortality of cricket nymphs caused by nematodes were submitted to regression analysis.

\section{Feeding preference of Gryllus sp. due to the presence of entomopathogenic nematodes}

Leaves of lettuce (Lactuca sativa L.), cultivar UFU 375, approximately $40 \mathrm{~cm}^{2}$, treated with distilled water or $S$. carpocapsae All (94 infective juveniles leaf ${ }^{-1} / 0.5 \mathrm{~mL} \mathrm{H}_{2} \mathrm{O}$ ) were offered to 3rd instar nymphs of Gryllus sp. in test with and without the possibility of choice of feeding.

The leaves treated with water and nematodes were placed either alone (test with no chance of choice) or together (test with a chance of choice) in Petri dishes $(15 \mathrm{~cm}$ diameter) containing $30 \mathrm{~mL}$ of $1 \%$ agar/water solution to keep the leaf turgid. One insect per dish was released; they were sealed with Parafilm ${ }^{\oplus}$ and kept in a climate-controlled chamber at $24 \pm 2^{\circ} \mathrm{C}, 70 \pm 10 \% \mathrm{RH}$ and photoperiod of 12:12 $\mathrm{h} \mathrm{L}: \mathrm{D}$. The presence of crickets feeding on lettuce leaves was evaluated at 16, 24 and 40 hours after insect release. Fifteen replicates for each treatment were used in each test, and the experiment was repeated twice.

In the test with no chance for crickets to choose, the data on feeding of Gryllus sp. were adjusted to the generalized linear model using software $\mathrm{R}$ version 3.3.3, with binomial distribution and logit link function. The presence of feeding was considered the successful event. The difference between the treatments was considered when the deviation provoked by the factor in analysis (deviance) was significant by the $\chi^{2}$ test at 0.01 of significance.

Regarding the preference of Gryllus sp. in the test with a chance of choice, the following behaviors were evaluated:

- no feeding of the insect;

- insect feeding without the nematode;

- insect feeding with the nematode;

- feeding on both leaves.

All behaviors within the three-time intervals stipulated in 15 repetitions. The patterns observed at each time were submitted to the $\chi^{2}$ test at 0.01 of significance, with the objective of evaluating if there is insect preference or not to the type of food offered.

\section{Gryllus sp. control in field conditions}

The test was conducted on rural property located in Monte Carmelo, Minas Gerais, Brazil (18³5'3,61'S, 47027’40,41”O; $890 \mathrm{~m}$ altitude), with area of $22.5 \mathrm{ha}$, cultivated with lettuce, sugarbeet, cabbage and tomato. The area is located in the domain of Plateau and Tablelands of the Paraná Sedimentary Basin, in the Southwest portion of the Brazilian cerrado, in the meso-region of the Triângulo Mineiro and Alto Paranaíba. According to the Köppen classification, the climate of the region is the Cwa type, with average annual temperature of $22^{\circ} \mathrm{C}$ and annual average rainfall of $1,500 \mathrm{~mm}$, with rains concentrating in six months, mainly in the summer period. The soil type is predominantly red clay latosol.

Gryllus sp. population in the area was previously evaluated using 10 traps, randomly distributed, prepared in two ways: five traps made of tow bags (moistened) and five of plastic canvas, both measuring $1.5 \times 1.0 \mathrm{~m}$. Under each trap 10 pieces (about $2 \mathrm{~cm}$ ) of chopped carrots were placed. The number of crickets in each trap was evaluated after seven days.

H. amazonensis $\mathrm{MC} 01$ at a concentration of 70,000 infective juveniles in $30 \mathrm{~mL}$ and also cadavers of T. molitor containing $H$. amazonensis ( 1 cadaver per $1 \mathrm{~m}^{2}$ ) were applied to each $\mathrm{m}^{2}$. The cadavers were wrapped in wheat flour in order to avoid predation by ants, and buried $3 \mathrm{~cm}$ deep in the soil. The useful area of the experiment was $800 \mathrm{~m}^{2}$. The nematodes were not applied in the control area. Ten days after nematode application, the cricket population was evaluated using the traps already described. The cricket populations of the treated and control areas were compared by the Student $t$ test.

\section{RESULTS}

\section{Virulence of entomopathogenic nematodes on Gryllus sp.}

There was a significant difference in the virulence of entomopathogenic nematodes from the nymphs of Gryllus sp. treated with the different nematodes and the control. H. amazonensis MC01 and S. carpocapsae All caused mortalities higher than $60 \%$ and were chosen to be evaluated in the later tests (Table 1).

\section{Concentration of infective juveniles on Gryllus sp.}

The mortality of Gryllus sp. nymphs increased from 26.6 to $53.3 \%$ and from 6.66 to $60 \%$ when concentrations of $\mathrm{H}$. amazonensis MC01 and S. carpocapsae All were increased from 100 to 600 infective juveniles dish ${ }^{-1}$, respectively. The linear regression equation describes the relationship between the mortality of Gryllus sp. and the concentration of entomopathogenic nematodes, as indicated by the determination coefficient of 0.98 for both nematode species (Fig. 1). 
According to the results obtained, it was possible to determine that the most effective concentration of $H$. amazonensis MC01 for controlling crickets was 400 infective juveniles dish ${ }^{-1}$ (since at 600 infective juveniles dish ${ }^{-1}$ there was no increase in mortality), while for $S$. carpocapsae the concentration of 600 infective juveniles dish ${ }^{-1}$ was considered to be the most effective under the tested conditions.

\section{Feeding preference of Gryllus sp. due to the presence of entomopathogenic nematodes}

The consumption of lettuce leaves treated and not treated with nematodes by the nymphs was not observed after 16 hours in any of the tests, with and without a chance of choice.

In the evaluations after 24 and 40 hours in the test with no possibility of choice, the crickets were feeding, regardless of the presence or not of nematodes. Thus, both treated and untreated leaves were consumed by crickets (Table 2).

Table 1. Mortality (\%) of Gryllus sp. due to the application of Heterorhabditis amazonensis MCO1, Steinernema carpocapsae All, Heterorhabditis amazonensis RSCO5 and Heterorhabditis amazonensis GL.

\begin{tabular}{lc} 
Treatment & $\begin{array}{c}\text { Mean \% mortality } \\
( \pm \text { SD)* }\end{array}$ \\
\hline Heterorhabditis amazonensis MCO1 & $66.7 \pm 25.1 \mathrm{a}$ \\
\hline Steinernema carpocapsae All & $63.3 \pm 28.8 \mathrm{a}$ \\
\hline Heterorhabditis amazonensis RSC05 & $56.7 \pm 25.1 \mathrm{a}$ \\
\hline Heterorhabditis amazonensis GL & $40.0 \pm 0.0 \mathrm{ab}$ \\
\hline Control & $0.0 \pm 0.0 \mathrm{~b}$ \\
\hline CV $(\%)$ & 45.21 \\
\hline
\end{tabular}

*Means followed by the same letter do not differ by Tukey's test $(p<0.05)$.
Regarding the test with a chance of choice, there was no significant difference between the treatments. Therefore, independently of nematode presence on the lettuce leaves, crickets have consumed them; there was no difference between treated leaves and untreated leaves. There was increase in the consumption of leaves, treated or not, after 40 hours of installing the experiment, which may be related to the longer period of absence of feeding (Table 3).

\section{Gryllus sp. control in field conditions}

The preliminary evaluation of the experimental area recorded the total of 19 live crickets in the plastic canvas traps and absence of insects in the tow bag traps (Table 4). After the nematodes had been applied via aqueous suspension and cadavers, no crickets were found in the traps. It was verified that there was significant difference between the treatments before and after the application of the nematodes by the Student $t$ test at $1 \%$ of probability (Table 4).

\section{DISCUSSION}

The virulence of entomopathogenic nematodes to insect hosts can be highly variable; it depends on factors associated with their biology. SMART (1996) verified that some species of nematodes are more effective against a particular group of insects when compared to another group. For example, Steinernema scapterisci Nguyen and Smart is effective in controlling mole crickets (Scapteriscus Scudder) and crickets, but it is not effective in controlling other insect pests, which demonstrates the importance of performing selection tests onentomopathogenic nematodes.
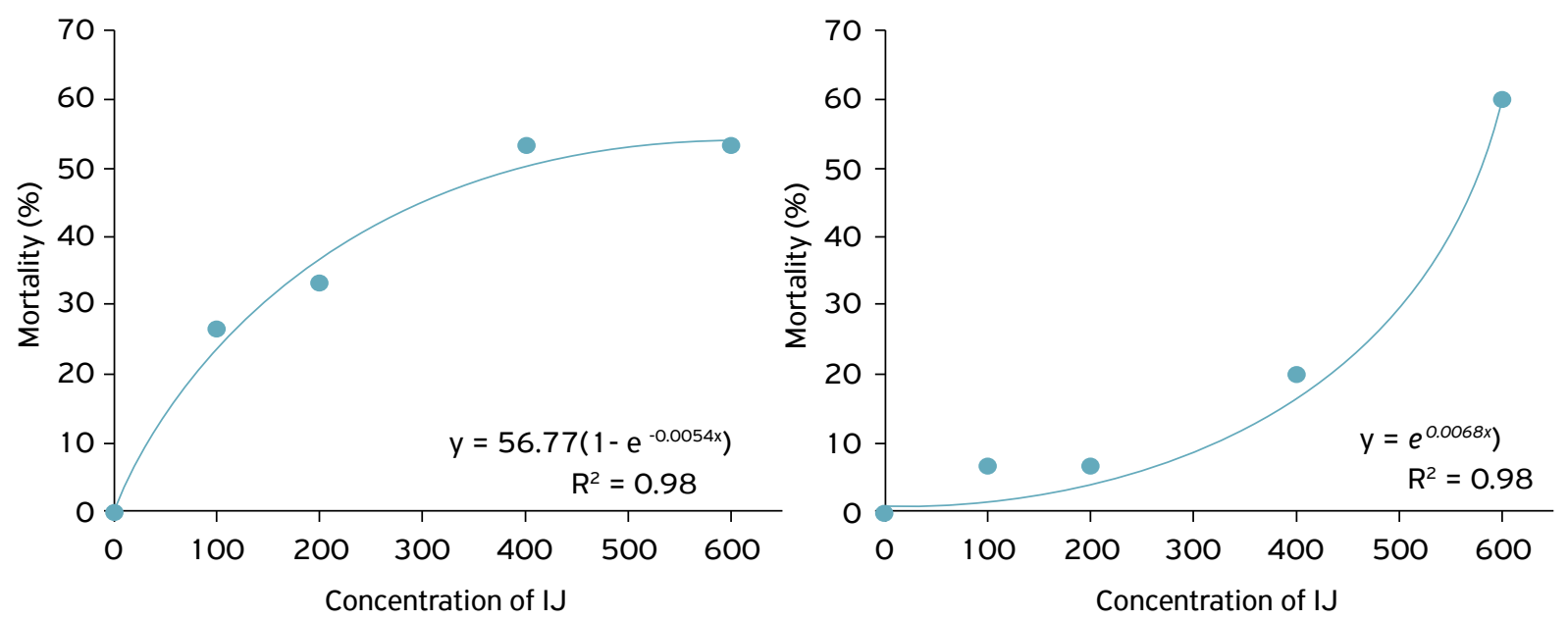

Figure 1. Mortality of Gryllus sp. as a function of the concentration of infective juveniles (IJ) of (A) Heterorhabditis amazonensis MCO1 and (B) Steinernema carpocapsae All. 
H. amazonensis $\mathrm{MC0} 1$ is an isolate native to the region of Monte Carmelo, Brazil, so it is adapted to the climatic conditions, enabling this species to obtain better results under field conditions. S. carpocapsae All is an exotic species, originally from Florida, United States, but with behavioral characteristics that distinguish it from the other nematodes used in the experiment.

Most nematodes of the genus Heterorhabditis are classified as having cruiser behavior, because they exhibit high mobility, exploiting signals associated with the hosts moving through the environment, probably attracted by volatile substances and $\mathrm{CO}_{2}$, being considerate more likely to find cryptic or sedentary insects deep in the soil profile. $S$. carpocapsae is classified as an ambusher nematode; it presents low mobility, and, in its moments of pause, it suspends the body, leaning on the tip of the tail, leaving the anterior part free and waiting for the passage of a host (a process known as nictation) (DOLINSKI; MOINO JÚNIOR, 2006). Thus, testing nematodes with different search behaviors under field conditions, both considered virulent to the insect, is a way to verify if the nematode search strategy influences the control success.

Therefore, in addition to nematode adaptation to the environment and host specificity, its search behavior should be taken into account, in order to reconcile the best biological characteristics between the nematode and the host, to potentiate the effectiveness of the control.

Regarding nematode concentration, LEITE et al. (2005) and DE PAULA BATISTA et al. (2011) also verified higher insect mortality when there was increase in the concentration of Heterorhabditis spp. (including $H$. amazonensis population) and Steinernema sp. when studying nematode effect on Mahanarva fimbriolata nymphs (Stål, 1854) (Hemiptera: Cercopidae). BARBARA; BUSS (2006) monitored the percentage of infection of $S$. scapterisci on mole crickets and observed that consecutive applications, increasing the amount of these organisms in the soil, elevate the mortality of the insects in the field. These results highlight the importance of defining the amount of infective juveniles to be applied in the field. ANDALÓ et al. (2010), studying entomopathogenic nematodes controlling Spodoptera frugiperda (Smith) (Lepidoptera: Noctuidae), found that mortality increases until a certain concentration, and after that there is stabilization or even decrease in mortality index.

Some insects can recognize the presence of the nematode in the soil and avoid the contact, as suggested by MASON;

Table 3. Leaves of lettuce consumed by Gryllus sp. with chance of choice between leaves treated with Steinernema carpocapsae All and control treatment (with water) after 24 and 40 hours.

\begin{tabular}{lccc} 
& \multicolumn{3}{c}{ 24 hours } \\
\cline { 2 - 4 } & N Observed & N Expected & Residual \\
\hline No feeding & 8 & 3.8 & 4.3 \\
\hline $\begin{array}{l}\text { Leaf with } \\
\text { water (control) }\end{array}$ & 5 & 3.8 & 1.3 \\
\hline $\begin{array}{l}\text { Leaf with } \\
\text { nematode } \\
\text { (treatment) }\end{array}$ & 1 & 3.8 & -2.8 \\
\hline Both leaves & 1 & 3.8 & -2.8 \\
\hline$\chi^{2}$ test & & 9.267 & \\
\hline Probability & & 0.026 & \\
\hline & & 40 hours & \\
\cline { 2 - 4 } & N Observed & N Expected & Residual \\
\hline No feeding & 4 & 5.0 & -1.0 \\
\hline $\begin{array}{l}\text { Leaf with } \\
\text { water (control) }\end{array}$ & 6 & 5.0 & 1.0 \\
\hline Both leaves & 5 & 5.0 & 0.0 \\
\hline$\chi^{2}$ test & & 0.400 & \\
\hline Probability & & 0.819 & \\
\hline
\end{tabular}

Table 4. Occurrence of Gryllus sp. in area cultivated with vegetables before and after the application of Heterorhabditis amazonensis MCO 1.

\begin{tabular}{lc}
\hline $\begin{array}{l}\text { Treatment } \\
\text { Without the application } \\
\text { of } H \text {. amazonensis }\end{array}$ & Number of Gryllus sp. \\
\hline $\begin{array}{l}\text { H. amazonensis by aqueous } \\
\text { suspension + insect cadaver }\end{array}$ & $0.0 \pm 0.0$ \\
\hline Student t Test & 8.1429 \\
\hline Probability & $<0.001$ \\
\hline
\end{tabular}

Table 2. Number of lettuce leaves with signs of feeding by Gryllus sp. in the presence (treatment) or absence (null) of Steinernema carpocapsae All over time in the test with no chance of choice.

\begin{tabular}{|c|c|c|c|c|c|c|c|c|}
\hline & & \multicolumn{4}{|c|}{24 hours } & \multicolumn{3}{|c|}{40 hours } \\
\hline & & $d f^{a}$ & Deviance & $\chi^{2}$ & Prob. & Deviance & $\chi^{2}$ & Prob. \\
\hline \multirow{2}{*}{ Test 1} & Null ${ }^{b}$ & 0 & \multicolumn{3}{|c|}{41.054} & \multicolumn{3}{|c|}{38.191} \\
\hline & Treatment $^{c}$ & 1 & 3.4661 & 37.588 & 0.062 & 0 & 38.191 & 1.000 \\
\hline \multirow{2}{*}{ Test $2^{d}$} & Null ${ }^{\mathrm{b}}$ & 0 & \multicolumn{3}{|c|}{36.652} & \multicolumn{3}{|c|}{41.054} \\
\hline & Treatment $^{c}$ & 1 & 1.4494 & 35.202 & 0.228 & 0.135 & 40.180 & 0.712 \\
\hline
\end{tabular}

$\mathrm{df}^{\mathrm{a}}$ : degrees of freedom; nullb: absence of Steinernema carpocapsae All; treatmentc: presence of Steinernema carpocapsae All; test $2^{\mathrm{d}}$ : performed 15 days after the first in order to ratify the results; prob.: probability. 
WRIGHT (1997), that observed that leaf-attacking pests are often able to perceive the presence of entomopathogenic nematodes. GAUGLER et al. (1994) found that the Japanese beetle - Popillia japonica Newman (Coleoptera: Scarabaeidae) - was able to remove more than $60 \%$ of the nematodes present in its cuticle, which led to a reduction in parasitism when in contact with $H$. bacteriophora. In the present work, it was noticed that Gryllus sp. did not distinguish between leaves containing infective juveniles or not, which reinforced the possibility of using entomopathogenic nematodes to control crickets. Even if the goal is to reach the soil, plants that keep nematodes on their leaves will not be avoided by insects.

Field results indicate the potential of the use of entomopathogenic nematodes for the control of crickets under the conditions tested. LEPPLA et al. (2007) observed that mole crickets killed by $S$. scapterisci aided in the dispersion of nematodes, and even after six months dead insects continued to be found in the traps. In the present work, no parasitized insects were found in the traps. However, there was $100 \%$ of reduction in the number of crickets found after the application of nematodes. S. scapterisci has already been used as a successful biological control agent for orthopterans (ADJEI et al., 2003; BARBARA; BUSS, 2005; ADJEI et al., 2006; FRANK et al., 2016), and nowadays $H$. amazonensis MC01 has showed as a potential natural enemy for control of Gryllus sp. Thus, further tests should be performed to verify the permanence of these nematodes in the field, in order to establish intervals for the next applications.

\section{ACKNOWLEDGMENTS}

The authors thank the Fundação de Amparo à Pesquisa do Estado de Minas Gerais (FAPEMIG) for financial support.

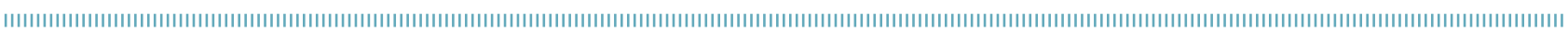
REFERENCES

ADJEI, M.B.; FRANK, J.H.; GARDNER, C.S. Survey of pest mole crickets (Orthoptera: Gryllotalpidae) activity on pasture in SouthCentral Florida. Florida Entomologist, v.86, n.2, p. 199-205, 2003. DOI: 0.1653/0015-404O(2003)086[0199:SOPMCO]2.0.CO;2

ADJEI, M.B.; SMART JR, G.C.; FRANK, J.H.; LEPPLA, N.C. Control of pest mole crickets (Orthoptera: Gryllotalpidae) in bahiagrass pastures with the nematode Steinernema scapterisci (Rhabditida: Steinernematidae). Florida Entomologist, v.89, n.4, p.532-535, 2006.

ANDALÓ, V.; SANTOS, V.; MOREIRA, G.F.; MOREIRA, C.C.; MOINO JUNIOR, A. Evaluation of entomopathogenic nematodes under laboratory and greenhouses conditions for the control of Spodoptera frugiperda. Ciência Rural, v.40, n.9, p.1860-1866, 2010. DOI: $10.1590 /$ SO $103-84782010005000151$

BARBARA, K.A.; BUSS, E.A. Integration of insect parasitic nematodes (Nematoda: Steinernematidae) with insecticides for control of pest mole crickets (Orthoptera: Gryllotalpidae: Scapteriscus spp.). Journal of Economic Entomology, v.98, n.3, p.689-693, 2005. DOI: 10.1603/0022-0493-98.3.689

BARBARA, K.A.; BUSS, E.A. Augmentative applications of Steinernema scapterisci (Nematoda: Steinernematidae) for mole cricket (Orthoptera: Gryllotalpidae) control on golf courses. Florida Entomologist, v.89, n.2, p.257-262, 2006. DOI: 10.1653/0015-4040(2006)89[257:AAOSSN]2.0.CO;2

BARBOSA, L.R.; IEDE, E.T.; SANTOS, F. Caracterização de danos de Gryllus sp. em plantas de eucalipto em laboratório. Pesquisa Florestal Brasileira, v.59, p.63-68, 2009. DOI: 10.4336/2012.pfb.59.63
DE PAULA BATISTA, E.S.; AUAD, A.M.; DE RESENDE, T.T.; DE OLIVEIRA MONTEIRO, C.M. Screening of entomopathogenic nematodes to control Mahanarva fimbriolata (Hemiptera: Cercopidae). Revista Colombiana de Entomología, v.37, n.2, p.198-202, 2011.

BRASIL. Agrofit. Available from: <http://agrofit.agricultura.gov.br/ agrofit_cons/principal_agrofit_cons>. Accessed on: Apr. 032017.

DOLINSKI, C.; MOINO JÚNIOR, A. Utilização de nematoides entomopatogênicos nativos ou exóticos: o perigo das introduções. Nematologia Brasileira, v.30, n.2, p.139-149, 2006.

FRANK, J.H.; SMART, G.C.; ADAMS, B.J. Infectivity and persistence of Steinernema scapteriscinematodes on pasture mole crickets in Florida. 2016. Available from: <http://edis.ifas.ufl.edu/pdffiles/ IN/IN4 1600.pdf>. Accessed on: Mar. 172017.

GASSEN, D.N. Manejo de pragas associadas à cultura do milho. Passo Fundo: Aldeia Norte, 1996. 127p.

GAUGLER, R.; WANG, Y.I.; CAMPBELL, J.F. Aggressive and evasive behaviors in Popillia japonica (Coleoptera: Scarabaeidae) larvae: defenses against entomopathogenic nematode attack. Journal of Invertebrate Pathology, v.64, n.3, p.193-199, 1994. DOI: 10.1016/SOO22-2011(94)90150-3

GRIFFIN, C.T.; BOEMARE, N.E.; LEWIS, E.E. Biology and behavior. In: GREWAL, P.S.; EHLERS, R.u.; SHAPIRO-ILAN, D.I. (Ed.). Nematodes as biocontrol agents. Wallingford: Cabi Publishing, 2005. p.47-64. 
KAYA, H.K.; GAUGLER, R. Entomopathogenic nematodes. Annual Review of Entomology, v.38, p.181-206, 1993.

LEITE, L.G.; MACHADO, L.A.; GOULART, R.M.; TAVARES, F.M.; BATISTA FILHO, A. Screening of entomopathogenic nematodes (Nemata: Rhabditida) and the efficiency of Heterorhabditis sp. against the sugarcane root spittlebug Mahanarva fimbriolata (Fabr.) (Hemiptera: Cercopidae). Neotropical Entomology, v.34, n5, p.785790, 2005. DOI: 10.1590/S1519-566X2005000500010

LEPPLA, N.C.; FRANK, J.H.; ADJEI, M.B.; VICENTE, N.E. Management of pest mole crickets in Florida and Puerto Rico with a nematode and parasitic wasp. Florida Entomologist, v.90, n. 1, p.229-233, 2007. DOI: 10.1653/0015-4040(2007)90[229:MOPMCI]2.0.CO;2

MASON, J.M.; WRIGHT, D.J. Potential for the control of Plutella Xylostella larvae with entomopathogenic nematodes. Journal of Invertebrate Pathology, v.70, n.3, p.234-242, 1997. DOI: 10.1006/jipa.1997.4695

MOLINA, J.P.; LÓPEZ, N.J.C. In vivo production of three entomonematodes with two infection systems in two hosts. Revista Colombiana de Entomología, v.27, p.73-78, 2001.

MOREIRA, H.J.C.; ARAGÃO, F.D. Manual de pragas do milho. 2009. Available from: <http://www.agrolink.com.br/downloads/manual\%20 de\%2Opragas\%2Odo\%2Omilho.pdf>. Accessed on: Mar. 172017.
NGUYEN, K.B.; SMART JR., G.C. Pathogenicity of Steinernema scapterisci to selected invertebrates. Journal of Nematology, v.23, n.1, p.7-11, 1991.

PARKMAN, J.P.; SMART, G.C. Entomopathogenic nematodes, a case study, introduction of Steinernema scapterisci in Florida. Biocontrol Science and Technology, v.6, n.3, p.413-420, 1996. DOI: $10.1080 / 09583159631389$

POTRICH, T.D.; LORINI, I.; VOSS, M.; STEFFENS, M.C.S.; PAVANI, D.P. Metodologia de criação de Tenebrio molitor em laboratório para obtenção de larvas. Passo Fundo: Embrapa Trigo, 2007. (Documentos On-line 82). Available from: <http://www.cnpt. embrapa.br/biblio/do/p_do82_12.htm>. Accessed on: May 042017.

SALVADORI, J.R. Pragas-de solo-em culturas graníferas. Passo Fundo: Embrapa Trigo, 1999. (Comunicado Técnico n. 26). Available from: <http://www.cnpt.embrapa.br/biblio/p_co26. htm>. Accessed on: May 042017.

SANTOS, G.P.; ZANUNCIO, J.C.; ZANUNCIO, T.V.; PIRES, E.M. Pragas de eucalipto. Informe Agropecuário, v.29, n. 242, p.4770, 2008

WHITE, G.F. A method for obtaining infective nematode larvae from cultures. Science, v.66, n. 1709, p.302-303, 1927. 